\title{
De la fotocopia al pdf: Juan Luis Martínez y Tan Lin*
}

\author{
From xerox to pdf: Juan Luis Martínez and Tan Lin
}

Felipe Cussen

Instituto de Estudios Avanzados Universidad de Santiago de Chile.

Correo electrónico: felipecussen@gmail.com

\begin{abstract}
En este ensayo reflexionaré sobre las posibilidades de apropiación literaria que permiten la fotocopiadora y el computador. Para ello, analizaré dos casos provenientes de contextos culturales muy diversos. El primero es el libro póstumo El poeta anónimo, de Juan Luis Martínez, desarrollado a lo largo de los ' 80 , y compuesto casi exclusivamente por fotocopias de otros libros, revista y periódicos. El segundo son dos obras recientes del poeta norteamericano Tan Lin, Seven Controlled Vocabularies and Obituary 2004. The Joy of Cooking, donde incluye fotografías, documentos y objetos escaneados, y Heath, en el que copia una gran cantidad de material de páginas web. Como se podrá observar, ambos autores están cerca de la noción del poeta como un "remixer", planteada por Vilém Flusser, pero además intentan reflejar la pérdida que implica cortar, copiar y pegar.
\end{abstract}

Palabras clave: Juan Luis Martínez, Tan Lin, apropiación literaria, conceptualismo

In this essay I'll reflect on the possibilities of literary appropriation related to xerox and computer technologies. I will analyze two cases from very different cultural contexts. The first is the posthumous book El poeta anónimo, by Juan Luis Martínez, developed throughout the ' 80 s, and composed almost entirely of photocopies of other books, magazines and newspapers. The second is two recent works of American poet Tan Lin, Seven Controlled Vocabularies and Obituary 2004. The Joy of Cooking, which includes scanned photographs, documents and objects, and Heath, which takes a lot of material from websites. Both authors are close to the notion of the poet as a "remixer" proposed by Vilém Flusser, but also try to show the loss that involves cutting, copying and pasting.

Keywords: Juan Luis Martínez, Tan Lin, literary appropiation, conceptualism

Recuerdo que hace mucho tiempo leí en la Revista del Domingo de El Mercurio una lista de los comentarios de algunos viajeros chilenos sobre distintas ciudades

Este ensayo forma parte del proyecto Fondecyt Regular \#1131136 "Samples y loops en la poesía contemporánea", del cual soy investigador responsable. Una versión preliminar fue leída el 19 de agosto de 2013 en el II Encuentro Nacional de Nuevos Medios, organizado por el programa de Estudios Visuales y Nuevos Medios de la Universidad de Chile y el Área de Nuevos Medios del Consejo Nacional de la Cultura y las Artes. Agradezco a Megumi Andrade por su colaboración en la investigación bibliográfica. 
del mundo de acuerdo a su comparación con Providencia: "Buenos Aires es como Providencia pero más grande", "Montevideo es como Providencia pero más tranquilo", o algo así. Lo mismo me sucedió la primera vez que leí al poeta norteamericano de origen chino Tan Lin: "Es como Juan Luis Martínez pero con internet”, pensé.

Juan Luis Martínez murió hace más de dos décadas. Los únicos libros que aparecieron en vida, La nueva novela y La poesía chilena, fueron autoeditados a fines de la década de los '70. Su poesía ocupa un lugar muy singular en la tradición chilena, pues lejos de una tendencia más romántica y discursiva, pone el énfasis en las complejas operaciones de lectura que debe llevar a cabo el lector para conectar una serie de textos e imágenes de diversa índole. En las entrevistas que otorgó se refería a un proyecto posterior en el que concentró sus energías, una obra "donde mi participación sea muy mínima" (2003: 75), "en la que no me pertenezca casi ninguna sola línea" (2003: 82), "donde yo no haya escrito nada" (2003: 106). Se creía que este libro había sido destruido, pero el año 2012 fue publicado sorpresivamente por la editorial brasileña Cosac \& Naify. Su título es El poeta anónimo ${ }^{l}$, y en su colofón se indica "Ediciones Archivo/ Santiago de Chile/ 1985", aunque Martínez sólo terminó de organizar el material en un archivador poco antes de morir.

El volumen que ahora conocemos corresponde, de acuerdo a lo que indican sus editores en la contratapa, a "um fac-símile do original do artista feito em xerox". Resulta paradójico referirse al "original" de un libro compuesto casi exclusivamente por fragmentos de periódicos, revistas y libros ${ }^{2}$. Esos materiales, de extensiones y texturas muy diversas, fueron recortados, pegados y luego fotocopiados. A primera vista parecería que las huellas de esas operaciones han sido "alisadas" durante este proceso, pero luego de ser colocadas sobre la bandeja de la máquina las sombras de los bordes u otras irregularidades persisten y adquieren relieve, casi como cicatrices. La diagramación es notoriamente irregular, lo que dificulta adicionalmente su legibilidad, y en algunos casos es muy probable que además se trate de hojas ya previamente fotocopiadas, pues las imágenes se notan muy oscurecidas, con una pérdida de su definición. Ese tono sombrío liga, de algún modo, este conjunto tan heterogéneo; tal como propone Luis Pérez-Oramas (2013), la fotocopiadora funciona como un filtro, pues se resalta el rango que tiende hacia el negro.

Juan Luis Martínez es sólo uno más de los muchos autores que han recurrido a la fotocopiadora como una herramienta clave dentro de sus poéticas. Fernando Pérez Villalón (2013) cita como uno de sus posibles antecedentes el libro Derechos de autor de Enrique Lihn. En efecto, este "cuaderno de recortes" está formado por poemas manuscritos, documentos escritos a máquina, y entrevistas y textos sobre su obra tomados de periódicos y revistas, todos ellos fotocopiados para integrar este volumen. Esta autoedición de factura bastante tosca le otorga evidentemente un halo de urgencia, casi subversivo. Algo parecido ocurrió, por ejemplo, con los miembros del Marginalismo en la época de la dictadura brasileña, que utilizaron el mimeógrafo y la fotocopia para conseguir una distribución más allá de los canales

Me refiero con más detalle a otros aspectos de la aparición de este libro en mi reseña "Primeros apuntes sobre $E l$ poeta anónimo" (2013).

2 La portadilla, el sumario y las títulos de capítulos y secciones parecen haber sido hechos en computador, y además hay algunos epígrafes escritos a máquina y un par de anotaciones manuscritas; supongo que en una edición "definitiva" estos elementos habrían sido homologados. 
editoriales instituidos (Wasem 2012: 95). Alessandro Ludovico destaca también la importancia de esta tecnología en los punks, quienes aprovecharon las facilidades para publicar sus fanzines y flyers (Ludovico 2012: 43), pero señala asimismo el interés que ocupó la propia máquina y sus procesos: "for example, the shades and contrasts obtained by re-copying a copy, the ability to 'photograph' objects placed directly upon the scanning window, and the strange effects that could be created by moving the original during the scanning process" (Ibid.: 44). Al respecto, un caso destacado en el ámbito de la poesía visual es el inglés Bob Cobbing, quien comenzó a utilizar la fotocopiadora desde 1984. Como él mismo indica en una entrevista, su trabajo implica una intervención basada en el movimiento: "when I'm working on the photo-copier I'm dancing round it and what I'm doing on the machine is movement and that movement then gets into the finished work which again is transformed into movement when I perform it" (Cobbing 2001). Estas obras (algunas de los cuales fueron recopiladas en Three sequences (2013)) no contienen ningún elemento verbal, sino que más bien corresponden a texturas completamente abstractas que hacen visibles los gestos involucrados en su producción. Algo similar se observa en el canadiense John Riddell (2013), quien también a fines de los '80 tomaba textos mecanografiados con una misma palabra repetida en columnas y los movía mientras los fotocopiaba, para crear superficies ondulantes.

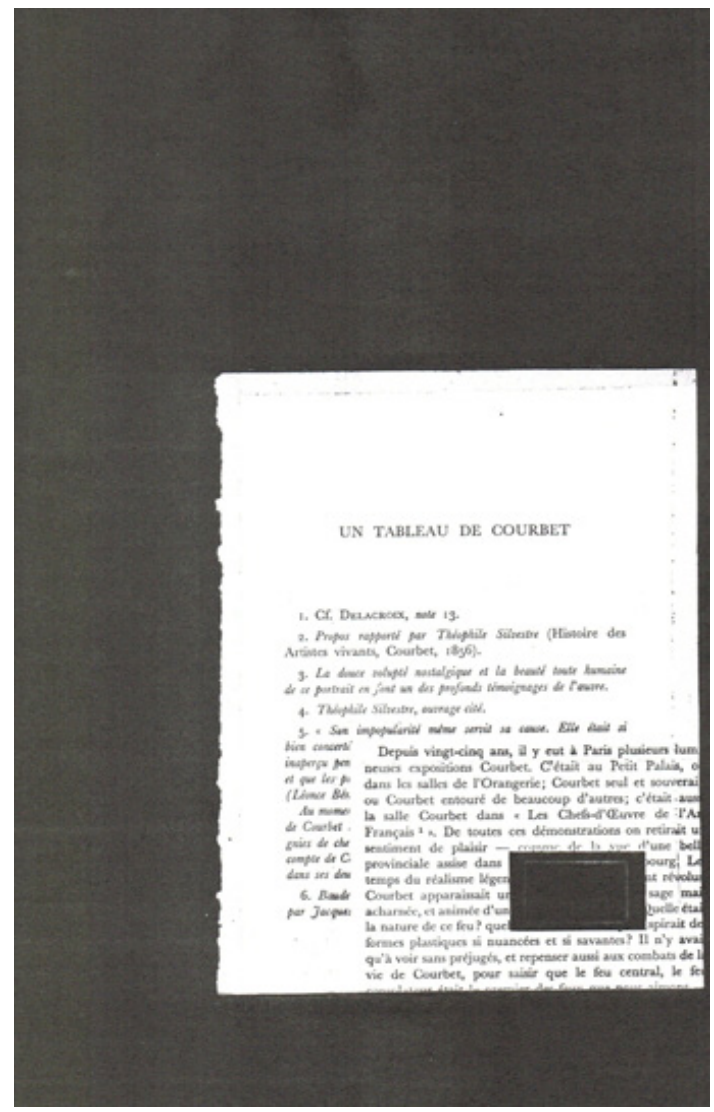



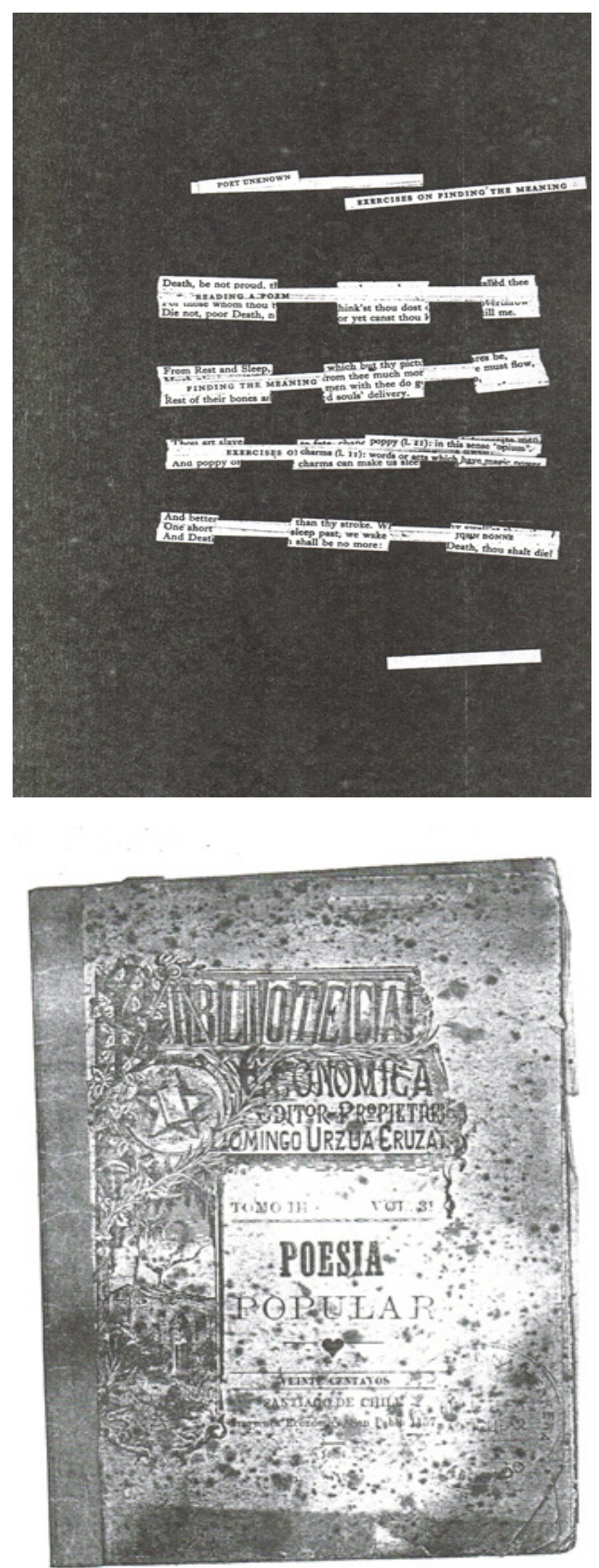


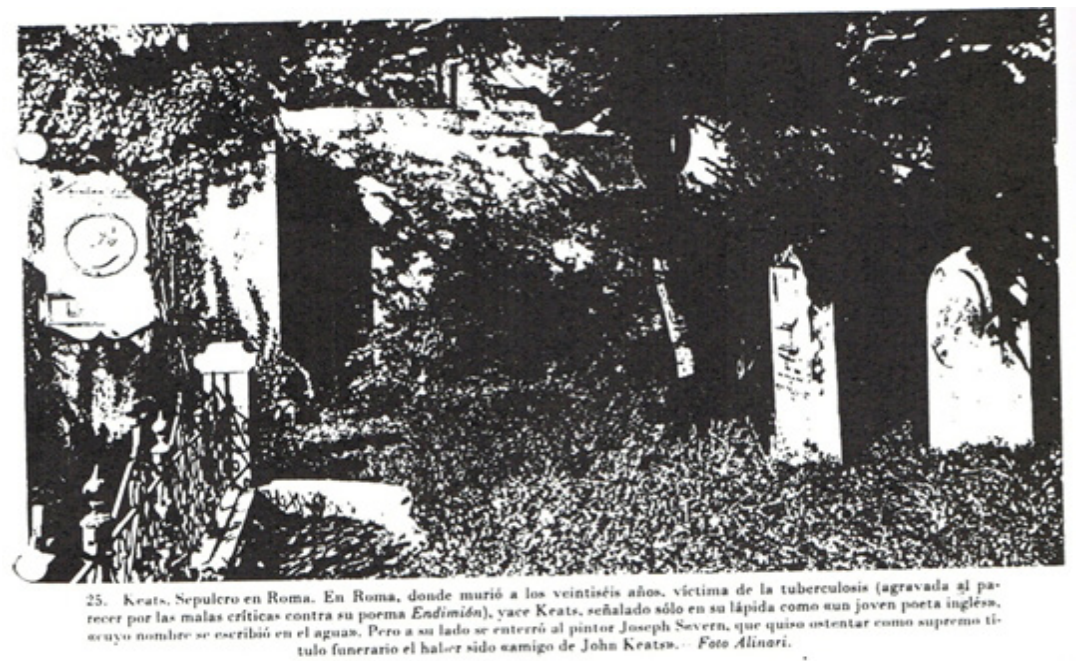

La fotocopiadora, entonces, ha ofrecido a los autores y agentes culturales nuevas posibilidades de edición y difusión, por una parte, y ha permitido nuevas formas de experimentación visual que involucran el movimiento, por otra. El libro de Juan Luis Martínez, sin embargo, no corresponde tanto a esos propósitos como al aprovechamiento de las facilidades técnicas para apropiarse e intervenir materiales ajenos. En ese sentido, creo que podría ligarse más a obras como Purloined: A Novel, del artista conceptual Joseph Kosuth, que como explican Craig Dworkin y Kenneth Goldsmith está compuesta enteramente "of single pages from more than a hundred different novels of various genres to form a single work. Each page is photocopied directly from its original source, thus resulting in a variety of typefaces and layouts" (Dworkin y Goldsmith 2011: 331). También podría pensarse en un vínculo con libros como That This de la poeta norteamericana Susan Howe (2010). A diferencia de Kosuth, esta autora sí manipula bastante los libros de los que se adueña, creando collages de textos muy fragmentados. Como ella misma destaca, aunque parezcan haber sidos diseñados mediante softwares como Photoshop, todo lo realiza manualmente: "All of that was all done by me cutting, taping, going to Xerox machines, coming back, doing it again" (Howe 2012). Considerando tanto a Kosuth como a Howe, estimo que El poeta anónimo se sitúa en un punto intermedio de los grados posibles de alteración de los materiales fotocopiados, pues, como se acaba de observar en la selección recién mostrada, hay secciones donde se limita a incluir páginas completas, y otras en las que recorta, reordena e incluso superpone pedazos más pequeños.

Aunque que se trate del facsímil de un borrador que no alcanzó a ser editado por Juan Luis Martínez, es relevante señalar su contraste con la cuidada apariencia de La nueva novela (1985), su obra más conocida. En ésta, la gran diversidad de fotografías y dibujos, distintos tipos de papeles e incluso objetos como un anzuelo y un grabado chino están combinados de manera muy precisa. No es extraño que muchos hayan resaltado su condición de artefacto o maquinaria de relojería. A partir de su apelación lúdica y didáctica al lector (Labraña 1999: 3), Juan Herrera destaca 
su carácter interactivo e incluso la propone como "una manifestación anticipada de la cultura electrónica (hoy representada con Internet) en la que se insiste en la relación animada entre los participantes de la red" (Herrera 2007: 10). Además, se anima a analizar su compleja estructura de alusiones y remisiones de distinta materialidad y pertenecientes a diversos campos del saber como un ejemplo de "poesía protohipertextual" (Ibid.: 17) ${ }^{3}$.

A mediados de los ' 80 , mientras se fraguaba El poeta anónimo, en Chile vislumbrábamos el fulgor de los avances tecnológicos que anunciaba el periodista Hernán Olguín en su programa "Mundo". Si le creemos a Joaquín Lavín, el autor de Chile Revolución Silenciosa, por ese entonces éramos el país latinoamericano con mayor cantidad de microcomputadores en las escuelas (Lavín 1987: 155) y el segundo en volumen de tráfico de computadores con Estados Unidos (Ibid.: 125), más de mil empresas utilizaban el correo electrónico, que funcionaba en una "casilla" que no queda en la oficina de correos, sino en la memoria del computador” (Ibid.: 127-28) y "el transmisor de facsímiles, verdadera fotocopiadora telefónica, conocida como "fax" " se vendía como pan caliente (Ibid.: 128). Los computadores, en definitiva, eran "parte esencial de la "revolución silenciosa"” (Ibid.: 122).

En medio de esa supuesta fiebre informática, resulta casi conmovedor imaginar a un poeta escribiendo con tijeras y goma de pegar como si hiciera una tarea en el jardín infantil. El arcaísmo se acentúa aún más al observar que parte importante de sus objetos de trabajo son libros antiguos, como si fuera el archivo de un naufragio. Hoy, a cerca de 30 años de distancia, la condición literalmente artesanal de sus prácticas resulta aún más distintiva, pues su aparición a destiempo resuena de manera opaca sobre el brillo excesivo de las pantallas de nuestros computadores.

Considero, sin embargo, que El poeta anónimo es algo más que un libro vintage, y me parece, en cambio, que se encuentra muy cerca de algunas escrituras actuales. En este caso particular, no se trata tanto de la interactividad a la que se refería Herrera, sino más bien de sus denodados esfuerzos por abolir las nociones de autoría y originalidad. Los procedimientos de apropiación son antiquísimos, y han sido practicados y teorizados a lo largo de todo el siglo XX, pero lo que resalta en este libro es su grado de radicalidad. En ese sentido, su entusiasmo por el pegoteo es sólo comparable al de una serie de escritores principalmente estadounidenses, pero también canadienses, ingleses, y de otros países, que en los últimos años han dado forma al "Conceptualism" o "Conceptual Writing"4. Juan Luis Martínez podría ocupar con total dignidad un lugar en la antología Against Expression, editada por Dworkin y Goldsmith, en la que además de una serie de poetas contemporáneos como Robert Fitterman, Vanessa Place, Christian Bök, Derek Beaulieu, Nada Gordon, Simon Morris, Jen Bervin o Steven Zultanski se compilan los pioneros ejercicios de reescrituras, listados y constricciones a cargo de Marcel Duchamp, Brion Gysin, John Cage, Georges Perec, Andy Warhol y el mismo Kosuth, entre otros.

Hugo Rivera-Scott también compara ambas obras, y señala que a diferencia de La nueva novela, El poeta anónimo presenta una mayor linealidad (2013: 11).

4 En su reciente libro Juan Luis Martínez's Philosophical Poetics, Scott Weintraub también relaciona a nuestro autor con los conceptos de "Unoriginal Genius" (Marjorie Perloff) y "Uncreative Writing" (Kenneth Goldsmith) desarrollados en torno al conceptualismo: "Martínez's own 'unoriginal' or 'uncreative' writing . . . is masterfully displayed in La nueva novela" (Weintraub 2015: 35). 
Estos nobles antecedentes no son la única causa del auge del conceptualismo. Para Goldsmith, su principal vocero, la principal explicación para que existan tantos escritores explorando las estrategias de copia y apropiación son los computadores (Dworkin y Goldsmith 2011: xviii). Replicar un texto mediante una máquina de escribir es lento, e implica tanto trabajo como los cut-ups de William Burroughs o los ya mencionados poemas visuales de Bob Cobbing (Dworkin y Goldsmith 2011: xviii-xix), pero hoy, gracias a la enorme facilidad y rapidez para copiar y pegar cualquier fragmento de texto, estaríamos comenzando a vivir la utopía de la escritura no creativa: "digitized language can be poured into any conceivable container: text typed into a Microsoft Word can be parsed into a database, visually morphed in Photoshop, animated in Flash, pumped into online text-mangling engines, spammed to thousand of e-mail addresses, and imported into a sound-editing program and spit out as music - the possibilities are endless" (Ibid.: xix). En las artes visuales, el cine, y particularmente la música, este frenesí se ha vivido con aún mayor intensidad. Gran parte de las canciones que escuchamos o que bailamos están construidas a partir de samples de otras grabaciones. Y el sampling, tal como lo definen Kembrew McLeod y Peter DiCola, no es más que "a form of the fine arts practice of collage, but one that is done with audio tools rather than scissors and glue" (2011: 36).

Juan Luis Martínez, ya lo sabemos, ocupó las tijeras y la goma. Pero parece que Tan Lin ${ }^{5}$, otro de los poetas conceptuales incluido en Against Expression, no. Si uno abre Seven Controlled Vocabularies and Obituary 2004. The Joy of Cooking, el libro que me provocó la brillante idea de pensar en la comparación con Martínez y que me ha obligado a escribir este ensayo, podría pensar que se trata de un catálogo de compras o una revista de arquitectura ${ }^{6}$. La extrañeza aparece cuando se intenta distinguir las fotografías o imágenes escaneadas de libros, una caja de fósforos o una tira de pastillas, pues son muy pequeñas y cuesta distinguirlas. El texto, por otra parte, mantiene un tono igualmente impávido pero perturbador. Entre otras cosas, se discuten los modos de lectura, o más bien no-lectura, que este mismo libro requiere: "What are the forms of non-reading and what are the non-forms a reading might take? Poetry $=$ wallpaper. Novel $=$ design object. Text as ambient soundtrack? Dew-champ wanted to create works of art that were non-retinal. It would be nice to create works of literature that didn't have to be read but could be looked at, like placemats" (Lin 2010a: 16). Resulta fácil ir pasando las páginas distraídamente, hasta que chocamos con objetos extraños, como el prólogo a una colección de Laura Riding, que ha sido escaneado desde una copia usada. La textura del papel antiguo, incluso con anotaciones a lápiz, emerge disonantemente desde el interior de un libro que en sus otras secciones hacía ostensible la limpieza y exactitud de una diagramación en un software de diseño.

Además de los libros que citaré a continuación, recomiendo revisar su página web: http://tanlin.tumblr.com en la que se muestran otros trabajos suyos en formatos como Powerpoint y video, y también su página dentro del sitio E-poetry: http://epc.buffalo.edu/authors/lin/, donde se recopilan entrevistas y reseñas sobre su obra.

6 En una entrevista de 2010 se refiere precisamente a este afán omnívoro: "I tried to included everything I could. In that sense, it was about putting everything, including the kitchen sink, into a book. I wanted to try to be as inclusive as possible. For me, inclusive meant touching on all the various genres, like architecture, photography and painting" (Lin 2010c) 

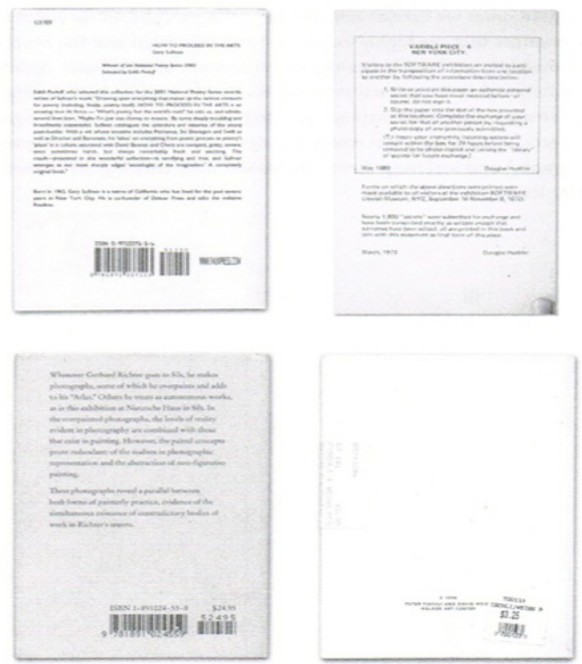

On rare occasions when I did cook, it was usually under the tutelage of Mr. Moll, his wife, and the first cookbook I ever owned, which is probably the only book I really think about when I think about myself growing into an adult. I did not after all want think about when I think about myself growing into an adult. I did not after all want to be a beggar at my table. The book is thames Beard st the only other book I kept in that apartment at the time was a copy of Self. Cooking. The only other book I kept in that apartment at the time was a copy of Self.
Portrait in a Convex Mirror by John Ashbery, which I had stolen from Viking Penguin Portrait in a Convex Mirror by John Ashbery, which I had stolen from Viking Penguin
when I had interned there the summer before. Some of these dates may not be quite when I had interned there the summer before. Some of these dates may not be quite right. The Beard book was a beautiful book. First of all it was a hardcover and had a dust jacket. Secondly, I had stolen it from a fancy bookstore on Madison Avenue. It was the first hardcover cookbook I ever owned and the first cookbook I ever stole. so it was the beginning of a corrupt library de haute cuisine. I read it nearly every night while at the Mölls'. I am not sure why I was so engrossed in it since I cooked so rarely, but I think it had to do with becoming what I perceived was a classy New Yorker. I don't know exactly what I was waiting for while I was growing up and reading and re-reading that book and not cooking much, but I know I was waiting for something, and whenever I look at a painting (I am a very good cook) or write a poem (I am a pretty good poet), it is hard for me not to remember the Theory and Practice of Cood Cooking and what James Beard said about how you should touch a steak with your hand in order to tell if it is done and that the color of food was the best way to taste it in advance. When I write a poem I often think of the hand that touches a steak to tell if it's done.

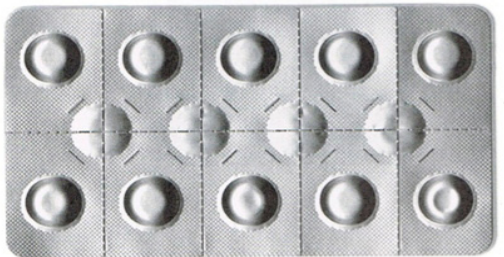


This Foreword stands apart from the prefaces I have successively written I for our book, in a period of twelve years. Its composition may be described as accumulative, progressing from an early personal statement through certain enlargements historically appropriate to its being of a more private character than the prefatory statements. It may be regarded as corresponding generally with the temporal expanse covered in the prefaces. The final portion generally with the temporal expanse covered in the prefce. The final portion being definitely in view at that time.

being definitely in view at that time. In the early 'thirties I began to feel a practical sense of urgency about some-
thing that had long troubled me. This was, that the use of words was in a bad thing that had long troubled me. This was, that the use of words was in a bad
way. The factor of urgency in my feelings was a product of accumulating awareness of the direct cause of the general state of word-use: it became plainer and plainer to me that the use of words was in a bad way because the knowledge of words was in a bad way. I committed myself to trying to make a new opening into the area of word-knowledge - the knowledge, that is, of what words mean. There is no conception of word-knowledge as a unity of work-

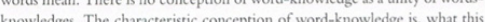
knowledges. The chacteristic conception of word-knowedge is, what this or that word means, there is no conception of tanguage-knowiedge as knowledge of the meanings of the words of a language in their interrelation as such. In my pursuit of my commitment, 1 did not meet an intellectually and morally companionate mind as to the things of language until I met Schuyler Brinckerhoff Jackson.

To the final stage of preparation of this book for possible publication, I had assumed that the preface I had written for it, as the completer of it for my husband and myself after he died, would be amply sufficient. What might need to be said preliminarily from the various persomally and thematically relevant poins of view seer of points of view seemed to have been siad, and, abo, as much of forifing ex-

mentary articles, as could be accommodated in the book without overreaching

Seven Controlled Vocabularies... ha expandido su vida en el mundo virtual mediante la página web "Edit Publications, 2010 Series, 11 Books Expanding Tan Lin's Seven Controlled Vocabularies and Obituary 2004. The Joy of Cooking, YouTube, Readings, Postcard \$ MediaWiki” (Lin 2010d). Con ocasión de una lectura en la Kelly Writers House de la Universidad de Pennsylvania en 2010, numerosos editores y autores intervinieron junto a Tan Lin esta obra mediante traducciones, variaciones, entrevistas, lecturas críticas, índices y postales. Uno de los volúmenes es Tan Lin's Seven Controlled Vocabularies: A Critical Reader, en el que simplemente se compilan citas de teóricos como McLuhan, Kittler, Attali, Deleuze, Jameson y otros. En Appendix, en cambio, se incluye el contrato con el editor y los informes de lectura de la publicación original por Wesleyan University Press. Incluso hay un complejo diagrama de flujos de todos los procesos y traspasos involucrados en estas operaciones. Todas estas extensiones están disponibles para descarga gratuita en pdf, y además en versión impresa mediante el sistema print-on-demand de lulu. com. Ése era el plan de Lin: "I didn't want a book to end with its publication but to begin there, be repurposed and remediated, transitioned from one published form to another" (Lin 2010b). Se trata de un perfecto ejemplo de lo que Marjorie Perloff ha denominado "differential texts", que existen en diversas materialidades (tanto en papel o en pantalla, como instalaciones, etc.), y de los que es imposible determinar cuál es la versión definitiva (Perloff 2006: 146). 
Post-It

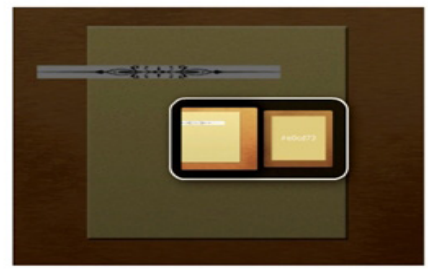

It definitely resembles the note taking products that were previously introduced with the ability of uploading handwritten notes to your
computer, but this seems to be something that would be used a lot more

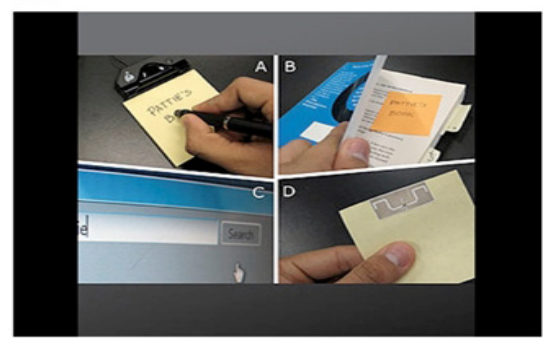

Instead of having to carry different post-its in your pocket, or writing dowr notes redundoner. the redundancy.

0
0
0
0
$\frac{1}{c}$
$\frac{0}{0}$
$\frac{0}{0}$
0
0
$\frac{1}{0}$
0
$\frac{1}{0}$
$z$

ANBAN BOARD (coordinated tasks)
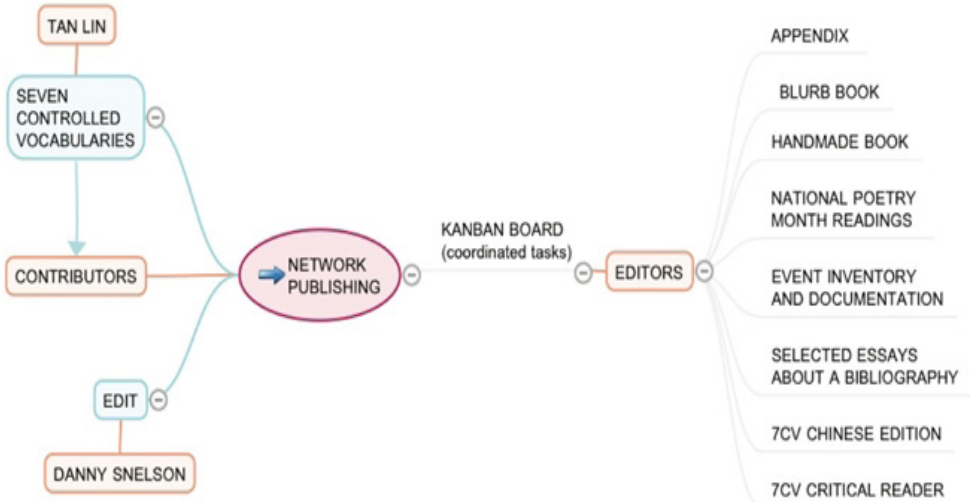


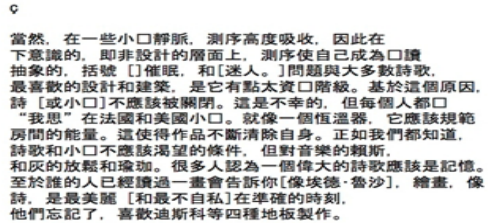

Cuando uno comienza a husmear, estos documentos se ven impecables, pero pronto se detectan algunas marcas de imperfección. Por ejemplo, en $7 \mathrm{CV}$ Chinese $2 n d$ Edit 2010, una traducción mediante Google Translate al chino, saltan varios caracteres vacíos que no superaron el traspaso. Estas huellas son mucho más evidentes en otro libro de Tan Lin, Heath (2007), que a nivel visual es el reverso de Seven Controlled Vocabularies, una verdadera explosión de basura digital. Como indica Kristen Gallagher, es evidente que todo el material ha sido pegado indiscriminadamente desde páginas web, sin ningún cuidado por el formato, como un trabajo plagiado por un estudiante inexperto, y las imágenes son muy feas, principalmente avisos comerciales (Gallaghger 2009: 701-702). Él mismo señala en sus entrevistas que es obvio que el no ha escrito directamente gran parte del libro: "There was no intent to deceive with Heath. It's pretty clear that much of the material wasn't written by me and this is reinforced by the copy and paste mode of design" (Lin 2009a). Danny Snelson, colaborador frecuente de Lin, lo denomina "transparent plagiarism" (Snelson 2007). Dentro del propio libro, además, se explicita su metodología, pues se listan los sitios web de los cuales se han extraído fragmentos o ideas, al igual que los motores de búsqueda, librerías e incluso los browsers ocupados. Por otra parte, como señala Lin en una entrevista posterior, esta caótica estructura permite emular en un texto impreso la forma de lectura de un usuario de internet: "Reading Heath is HARD. It's hard to parse, it's hard to figure out what it 'means.' / No, reading Heath is EASY. If you just relax a little and let yourself move freely through the text, if you skip over half of it because you already get it, which is what anyone does when they jump from one link to another link" (Lin 2009b). 


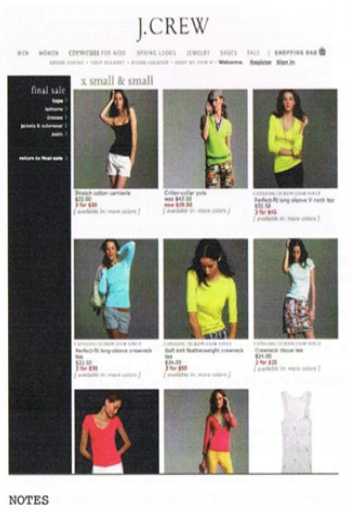

HELENA is " perm.

She has lived in many houles.
HELENA ZHANG-

20

STUDIU ART, VIDEOS

G HINESE AMERILAN

SPRRADK REAPER
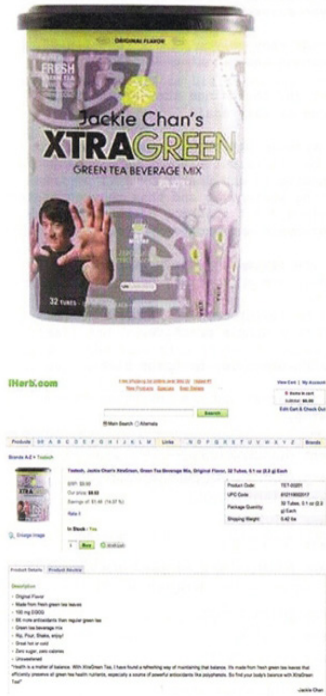

that she wore to yoga and the colors that she wore are a generalized

and their emotions are approximate and function as labels

and this is true. and this is not true

AUTOBIOGRAPHY

0 Davis, $C A \quad 5$ Cambridge, MA

1. St. Louis, MO 6. Queens, NY

2. Queens, NY 1. Valencia, CA

3. Taipei, Taiwan 8. Queens, NY

4. Queens, NY 9. Taipei, Taiwan

)
Made in Jainner. My fanity moned to the thats

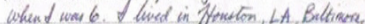

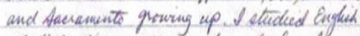

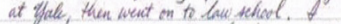

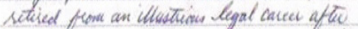
10 monith. How tha working at a mompopit

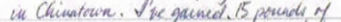

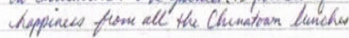



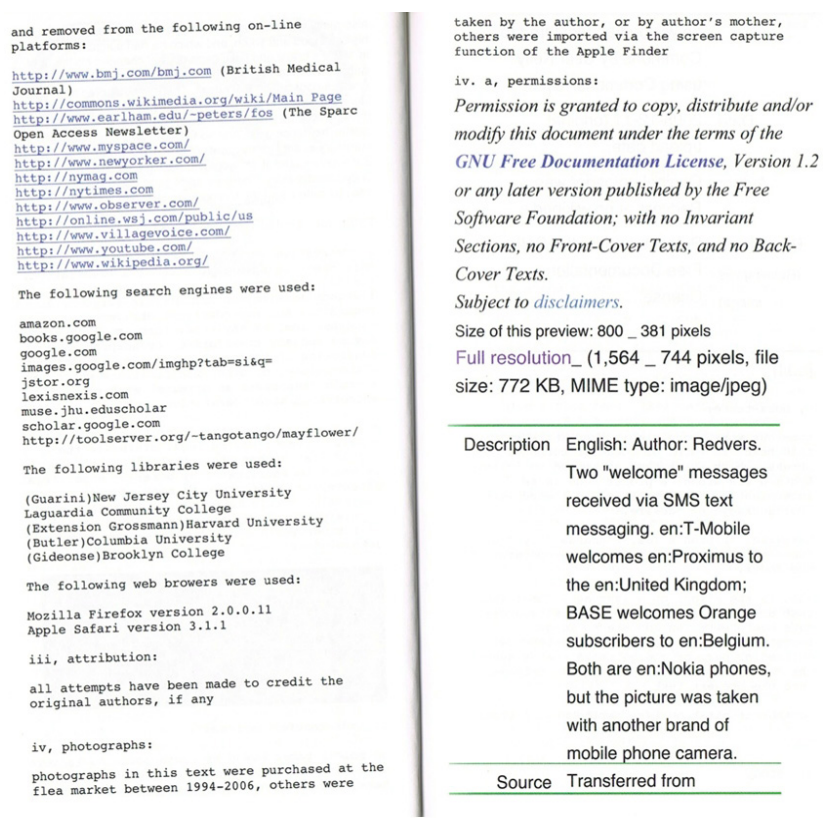

Refiriéndose tanto a Heath como a Seven Controlled Vocabularies, Lin menciona su interés por evidenciar la condición tecnológica del libro como una plataforma medial por la cual circula mucha información irrelevante, "much like a broadcast medium like TV or a narrow-cast medium like Twitter or Tumblr" (Lin 2012). Un libro sería, entonces, un canal que permite este flujo sin ninguna discriminación ni corrección, es decir, sin criterio editorial. Es esa condición de su escritura, creo, la que inicialmente detonó mi interés por vincularlo con Juan Luis Martínez, quien también apila materiales prestigiosos y degradados para poner a prueba las expectativas de coherencia y legibilidad. En ambos casos, asimismo, uno percibe que se trata de proyectos que, una vez iniciados, se le fueron de las manos a sus autores, como el mismo Martínez lo hizo ver: "en este último trabajo en el que estoy he dejado que el libro se autogenere. Yo he ido cumpliendo con una función de instrumento del lenguaje" (Martínez 2003: 81).

Martínez y Lin coinciden con el nuevo modelo de poeta que Vilém Flusser avizoraba en Does Writing have a Future?, publicado originalmente en 1987: un poeta que no confía en la inspiración de las musas, que no se identifica como autor sino como un "remixer", como un diseñador de información, como un "language technician" (Flusser 2011: 74-75). Pero hay un aspecto en común que me parece mucho más relevante para destacar: la conciencia de la pérdida que implica cortar, copiar y pegar. Ya veíamos que en El poeta anónimo Martínez se había preocupado por dejar las costuras de este proceso a la vista, tanto en la diagramación imperfecta como en la calidad dudosa de algunas fotografías. En Heath, de Lin, también resulta muy patente la degradación de las imágenes trasladadas con baja resolución, y, por si quedara alguna duda, incluye una nota al pie en la que cita el artículo "Computer Graphics: 
A Semi-Technical Introduction” de Friedrich Kittler: ““...digitalization, in terms of our perception, always also means distortion. The crackling noise, or, technically speaking 'quantization hiss' looming in digitally recorded music occurs in computer images as a stepped effect or interference, as an illusory discontinuity or continuitiy' (33)" (LIN 2007: s/n). Como un comentario a esta nota, en un artículo en línea sobre Heath, Danny Snelson (2007) da un paso más e incluye una versión escaneada del libro completo. Lo interesante es que en realidad el libro está copiado dos veces, y la segunda es prácticamente indescifrable debido a su pobrísima definición.

This work is licensed under the Creative
Commons Attribution-Share Alike 3.0 Commons Attribution-Share Alike 3.0
Unported License. To view a copy of this license, visit

http://creativecommons.org/licenses/bysa/3.0/ or send a letter to Creative Commons, 171 Second Street, Suite 300, San Francisco, California, 94105, USA.

\section{(c) 0}

On MondayJul 7, 2008, at 2:04 PM, Eric Laine wrote:

$<$ FN_cover_07-07-08.pdf>
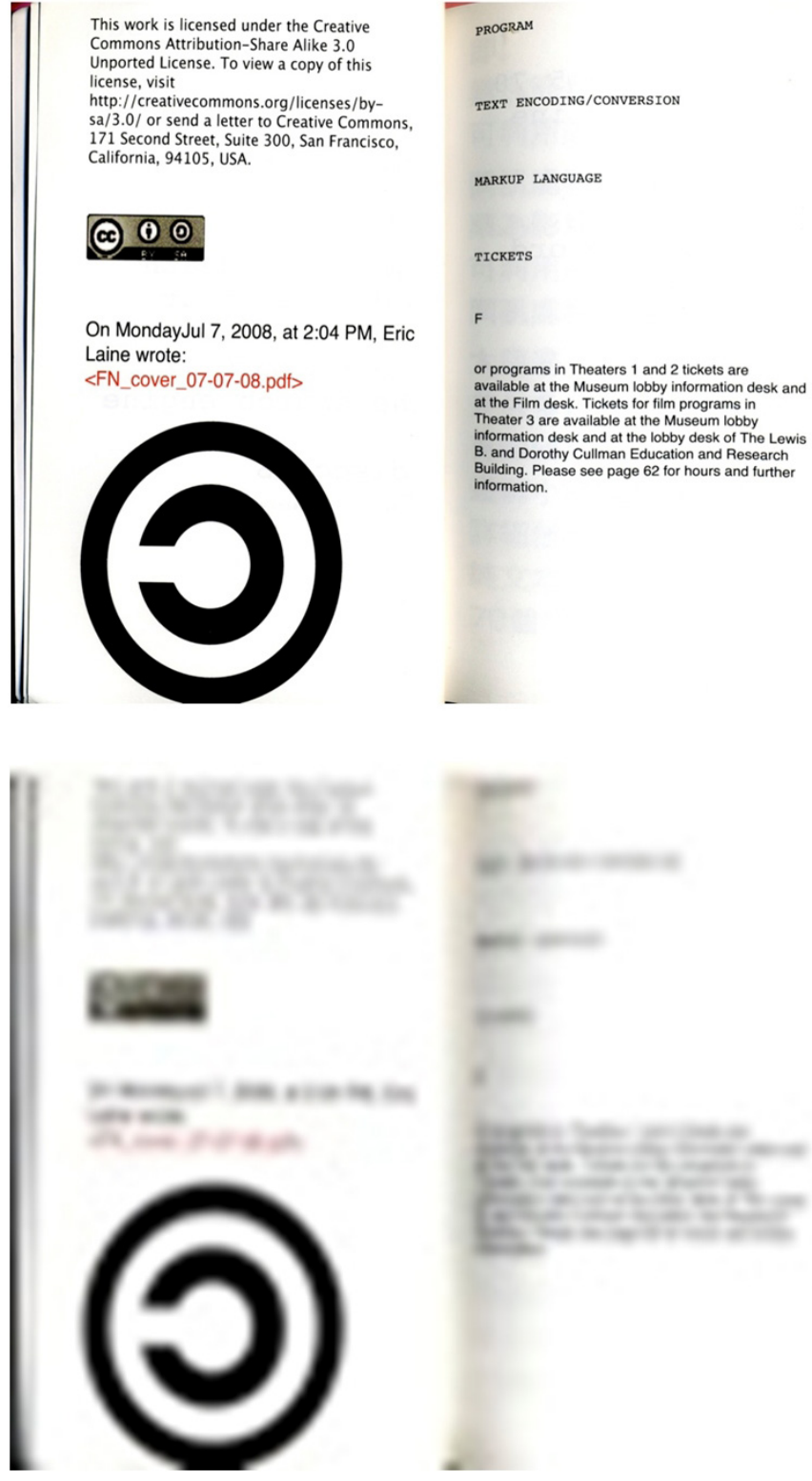
En consonancia con Kittler, Lev Manovich discutía en El lenguaje de los nuevos medios de comunicación la creencia común de que no existe pérdida de calidad en las copias digitales, pues las limitaciones del software y el hardware obligan a una compresión para poder almacenarlas: "mientras que, en teoría, la tecnología informática supone la duplicación perfecta de los datos, su uso real en la sociedad contemporánea se caracteriza por la pérdida de datos, la degradación y el ruido" (Manovich 2006: 102-3). Así ha seguido ocurriendo al menos en el caso de la música, donde hoy reina el formato mp3 por sobre otros de mayor definición pero que ocupan más espacio. Aunque quizás en algún tiempo más la disponibilidad tecnológica permitan guardar y difundir sin pérdida los archivos digitales, la escritura actual de Lin no oculta esa degradación, más bien la fetichiza.

Al igual que Martínez, Lin también concibe la necesidad de exponer sus técnicas de apropiación como su principal mérito, casi como un juego de niños, pero, como señalé, me llama aún más la atención la condición melancólica que termina por evidenciarse en ambos. Es cierto que en Martínez prima una intensidad patética, como si intentara una última defensa de la literatura, mientras que Lin disuelve los límites de ésta con relajo y desprendimiento. Martínez no es tan cool como Lin. Pero los dos se encuentran igualmente lejos de los discursos optimistas de muchos profetas de los nuevos medios, e incluso de la constante autoafirmación y seguridad de Kenneth Goldsmith, que pareciera sonreír tan contento como Joaquín Lavín cuando escribía su revolución silenciosa. Juan Luis Martínez y Tan Lin, en cambio, prefieren hacer gala de su laconismo, de su escepticismo, de sus vacíos y errores. Martínez, que de alguna manera se sentía hermano de los antiguos poetas chinos, estaría orgulloso de sentarse junto a Lin.

\section{OBRAS CITADAS}

Cobbing, Bob. 2013. Three sequences. Ed. Lawrence Upton. La Farge: Xexoxial Editions. 2001. "The Point About Criticism Is That It Is Frequently Wrong". Entr. W. Mark Sutherland. [Thursday, April 19, 2001, London, England]. UbuWeb. http://www.ubu. com/papers/cobbing_sutherland.html

Cussen, Felipe. 2013. "Primeros apuntes sobre El poeta anónimo”. Paniko, 25 mar. 2013. http://www.paniko.cl/2013/03/primeros-apuntes-sobre-el-poeta-anonimo/

Dworkin, Craig y Kenneth Goldsmith. 2011. Against Expression. An Anthology of Conceptual Writing. Evanston: Northwestern University Press.

Flusser, Vilém. 2011. Does Writing have a Future? Minneapolis: The University of Minnesotta Press.

Gallagher, Kristen. 2009. "The Authorship of Heath Ledger in the New Reading Environment; on Tan Lin's Heath: Plagiarism/Outsorce”. Criticism, vol. 51, nº 4, fall 2009: 701-709.

Herrera, Juan. 2007. "La nueva novela de Juan Luis Martínez: Poesía protohipertextual en el contexto de la videósfera". Acta Literaria $\mathrm{n}^{\circ}$ 35, II Sem. 2007: 9-27.

Howe, Susan. 2012. "The Art of Poetry No. 79”. Entr. Maureen N. McLane. The Paris Review, $\mathrm{n}^{\circ}$ 203, winter 2012. http://www.theparisreview.org/interviews/6189/the-art-of-poetryno-97-susan-howe

. That This. 2010. New York: New Directions.

Labraña, Marcela. 1999. "La Nueva Novela de Juan Luis Martínez y la cultura oriental". Vértebra $\mathrm{n}^{\circ}$ 4, sept. 1999: 2-6. 
Lavín, Joaquín. 1987. Chile Revolución Silenciosa. Santiago: Zig Zag.

Lin, Tan. 2012. "A Book is Technology: An Interview with Tan Lin”. Entr. Angela Genusa. Rhizome, 24 oct. 2012. http://rhizome.org/editorial/2012/oct/24/interview-tan-lin/ 2010d. "Edit Publications, 2010 Series, 11 Books Expanding Tan Lin's Seven Controlled Vocabularies and Obituary 2004. The Joy of Cooking, YouTube, Readings, Postcard \$ MediaWiki”. http://aphasic-letters.com/edit/publications.html 2010c. "Ambiently Breaking Reading Conventions: Colin Marshall Talks to Experimental Poet Tan Lin". 3QuarksDaily, 5 jul. 2010. http:/www.3quarksdaily. com/3quarksdaily/2010/07/ambiently-breaking-reading-conventions-colin-marshalltalks-to-experimental-poet-tan-lin.html

2010b. "Tan Lin: Enhancing the Book". Entr. Asher Penn. Art in America. 11 jun. 2010. http://www.artinamericamagazine.com/news-opinion/conversations/2010-06-11/ $\tan -\operatorname{lin} /$

. 2010a. Seven Controlled Vocabularies and Obituary 2004. The Joy of Cooking. Middletown: Wesleyan University Press. 2009b. "PLAGIARISM: A response to Thomas Fink". Otholits, $\mathrm{n}^{\circ}$ 14, southern winter 2009, 26 jun. 2009. http://the-otolith.blogspot.com/2009/06/tan-lin-plagiarismresponse-to-thomas.html

2009a. "Tan Lin Interviewed". Entr. Chris Alexander y otros. Galatea Resurrects \#12, 18 mayo 2009. http://galatearesurrection12.blogspot.com/2009/05/tan-lininterviewed.html . Heath. 2007. La Laguna: Zaesterle.

Ludovico, Alessandro. 2012. Post-Digital Print. Eindhoven: Onomatopee.

Manovich, Lev. 2006. El lenguaje de los nuevos medios de comunicación. La imagen en la era digital. Trad. Òscar Fontrodona. Buenos Aires: Paidós.

Martínez, Juan Luis. 2012. El poeta anónimo. São Paulo: Cosac \& Naify. 2003. Poemas del otro. Poemas y diálogos dispersos. Ed. Cristóbal Joannon. Santiago: Ediciones Universidad Diego Portales. . La nueva novela. 1985. $2^{\mathrm{a}}$ ed. Santiago: Ediciones Archivo.

McLeod, Kembrew y Peter DiCola. 2011. Creative License. The Law and Culture of Digital Sampling. Durham: Duke University Press.

Pérez-Oramas, Luis. 2013. "O eterno retorno de Juan Luis Martínez". Folha de S. Paulo, 20 enero 2013. http://www1.folha.uol.com.br/ilustrissima/1217250-o-eterno-retorno-dejuan-luis-martinez.shtml

Pérez Villalón, Fernando. 2013. "De la antropofagia al anonimato: la apropiación como procedimiento compositivo en Augusto de Campos y Juan Luis Martínez". Ponencia leída en Coloquio "Reciclajes textuales y sonoros", Universidad Alberto Hurtado, 17 de mayo de 2013.

Perloff, Marjorie. 2006. "Screening the Page/Paging the Screen: Digital Poetics and the Differential Text". New Media Poetics: Contexts, Technotexts, and Theories. Eds. Adelaide Morris y Thomas Swiss. Cambridge: The MIT Press: 143-62.

Riddell, John. 2013. Writing Surfaces. Selected Fiction of John Riddell. Eds. Derek Beaulieu y Lori Emerson. Waterloo: Wilfrid Laurier University Press.

Rivera-Scott, Hugo. 2013. "Notas para una cautelosa entrada en el oscuro objeto de ceniza que es El Poeta Anónimo de Juan Luis Martínez". Aproximación del Principio de Incertidumbre a un proyecto poético. Valparaíso: D21 Proyectos de Arte / Parque Cultural de Valparaíso, 2013: 9-15. http://pcdv.cl/web/wp-content/uploads/2014/01/ JLMartinez.pdf

Snelson, Danny. 2007. "HEATH, prelude to tracing the actor as network". Aphasic Letters. http://www.aphasic-letters.com/heath/ 
Wasem, Marcos. 2012. "Cilindros de cera, linotipos, fotocopias y pixels". Revista de Crítica Literaria Latinoamericana, año XXXVIII, $\mathrm{n}^{\circ}$ 76, $2^{\circ}$ sem. 2012: 81-99.

Weintraub, Scott. 2015. Juan Luis Martinez's Philosophical Poetics. Lewisburg: Bucknell University Press. 
